\title{
THE INFLUENCES OF PSYCHOLOGICAL WELL BEING AND MEANING OF LIFE TOWARD WOMEN'S LEVEL OF RELIGIOSITY ON THE EXILE RITUAL TRADITIONS "NUHUNE"
}

\author{
${ }^{1}$ Charla Wattimury, ${ }^{2}$ Susana Prapunoto, ${ }^{3}$ A. Ign Kristijanto \\ lievecharla@gmail.com \\ Magister Science Of Psychology Universitas Kristen Satya Wacana Salatiga, Indonesia
}

\begin{abstract}
This research is aimed to know the influence differences of Psychological WellBeing and Meaning of Life toward the level of Religiosity of both Primigravida and Multigravida women. The number of participants in this research was 150 women of Nuaulu Tribe of Central Maluku which was divided into two groups; 75 Primigravida women, and 75 Multigravida women. The method being used to collect the data was by distributing questionnaire. The scales used in this research were from Psychological Well-Being, Meaning in Life, Glock's Religiosity. The data collection was done by proportional stratified random sampling. The results of this research indicated that Psychological Well-Being and Meaning of Life which were done simultaneously influenced toward the level of Religiosity of both Primigravida and Multigravida women significantly.
\end{abstract}

Keywords: Meaning of Life, Multigravida, Primigravida, Psychological Well-Being, Religiosity

\section{Introduction}

In some inland areas in the Southern parts of Indonesia, the cultural practice of sending women being pregnant and giving birth into the exile since it is considered as an unclean person, a bearer of catastrophes, and a cause of magical inability of the husbands, is still taking place. This phenomenon, women in the exile, needs to be an important concern. It is not only because of the level of maternal and child deaths, the health of mothers and children especially those suffering from acute respiratory system, but also the psychological experiences that needs to be seen as a unique fact and examined.

The Health Agency of Central Maluku regency (2008) reported that the level of maternal and child mortality in the region was quite high. It happened because of the location, economics background of the people, medical professionals insufficiency especially midwives in the remote areas, the low level of knowledge among the community regarding health awareness, and the low level of contribution of the community in health programs. While data taken from Public Health Center of Tamilouw (one among other regions where Nuaulu people stayed) mentioned that the level of maternal and child mortality in 2007 reached $71,88 \%$ and increased to $73,19 \%$ in 2008 , before decreased to $60,67 \%$ in 2009[4]. The reason behind this fact was because the local people did not have enough knowledge about health factors in the process of giving birth. Witch-doctors (or Pina Piane in the local language) were the ones whom the local people rely on during the delivery process, and the witch-doctors normally used only traditional tools such as pieces of bamboo to cut the umbilical cords, dried leaves of 
Lanzones trees to dry the umbilicus, and Monon leaves to ease blood circulatory, also to do the relentless fumigation in the huts. Nuaulu tribe believes that by doing the fumigation, mothers and their babies would be stronger and healthier.

The tradition of exile gives fear to the women of Nuaulu tribe especially those who undergo the practice. It happens because the tradition requires them to undergo it to the end, while to the Nuaulu, the blood of a woman is forbidden since it is believed to be able to disable the magical power owned by the husbands or men. Hence, every woman who is under her period or giving birth must go for an exile into a 12-meter per square hut for at least 40 days to prevent catastrophes from happening to the Nuaulu especially men[5]. The punishment to those who disobey is being expelled because they would be considered to bring catastrophe for all their lifetime. This becomes the reason to Nuaulu people to obey all the rules set by the chief of the tribe[6]. The ritual policies must be obeyed by all. Psychological unreadness of women who are undergoing the tradition would impact their level of anxiety and fears. These anxiety and fears would give negative impacts to the lives of mothers and the babies during the pregnancy to the delivery. Psychologically, anxious mothers could influence the condition of the babies, so the babies would also become easily anxious and it would impact their lives when growing. Flouri, Ioakeimidi, Midouhas, Ploubidis[7] examined the level of anxiety and psychological pressures of women who were being pregnant and giving birth. The result from the distress typology of mothers suffering from psychological could be seen from the attitude of their daughters. They tended to be strongly difficult in making right decisions, show anserine behavior when making decision even though they had already been corrected by others.

In addition to that, Noonan, Burns, Violato[8] also found the relationship of distressed mothers that significantly influenced their children's behavior. It was obvious since the anxious mothers could stimulate the speed of the children's heartbeats and also adrenalin secretion which would cause the decline in the bloodstream. This would also weaken the contraction in the womb which prolonged the delivery process[9].

Those effects might endanger mothers and their babies. Primigravida mothers tended to see that giving birth to a child was identical to the most frightening, painful, and stressful compare to any other occasions in life[10]. Astria[11] also supported that from 158 participants, the level of anxiety of primigravida mothers reached $66,2 \%$ while that of multigravida mothers was only 42,2\%. Furthermore, Indrawati[12] mentioned that from 20 participants of primigravida mothers, $75 \%$ or 15 participants suffered from intermediate level of anxiety, while the rest $25 \%$ or equal to 5 participants only suffered from low level of anxiety. The level of anxiety of primigravida mothers was higher than that of multigravida mothers. Some research showed that the average of primigravida mothers suffering from the intermediate level of anxiety to the heavy one occurred during the third trimester or close to the delivery process. Those researches had given foundation that pregnancy status (gravidity) was proven to influence the level of anxiety on the mothers before giving birth. Besides, it was mentioned that the proportion of anxiety occurred most on primigravida mothers than multigravida mothers. It happened because primigravida mothers had not had the experiences of giving birth before[13]

\section{Literature Review}

Ryff[1] mentioned that psychological well-being is a state when an individual is able to have a self-acceptance completely, able to establish a warm relationship with others, able to have independence toward social pressures, able to control external environment, able to have meaning of life, and able to realize his potential values continually. Ryff (in Amawidyati[14]) 
compiled the six dimension of psychological well-being, they were self-acceptance, positive relations with others, autonomy, environmental mastery, purpose of life, and personal growth. Frankl[15] also stated that to put meaning of life was the process of introspection of someone's life with a joyful heart, have a life purposes, be able to adapt the environment, also be strong when facing problems, and realize that every cloud has a silver lining. Frankl[16] stated that there were three aspects under giving a meaning in life, they were free will, willingness to have a meaningful life, and the meaning of life itself. While for religiosity, Glock and Stark (in Azam, [17]) mentioned that religiosity could be framed in five dimensions which had impact toward human behavior aspects that were related to style of living and individual behavior. Those five dimensions introduced by Glock and Stark were the dimension of faith, ritualistic, experience, knowledge, and consequences[3].

Among previous researches done in Nuaulu, one of them was a study about traditionalism and patriarchy culture of Nuaulu women by Nina[5]. The study analyzed the roles and position of Nuaulu women within the tribe, while a study about the local Nuaulu culture was done by Utami[6] which was about the culture of Nuaulu tribe, also a research about the cultural rituals of Nuaulu tribe as an attraction in eco-tourism was done by Latupapua[18]. These research analyzed about traditional rituals practiced in Nuaulu as an attraction in eco-tourism and was considered to be able to improve the economy of NuaNea village where Nuaulu tribe was. In the other hand, Setyowati[4] conducted a research from the perspectives of health, and it was about studying the practice of Nuaulu women giving birth in the exile. Until now, there had not been a research which examines the psychological aspects of Nuaulu women undergoing the exile. Hence, the researcher found it important to examine the psychological sides of mothers undergoing the ritual, especially about the influences of Psychological Well-Being and Meaning of Life toward the level of Religiosity of the local people.

This research was done especially for mothers who were undergoing the exile during the $9^{\text {th }}$ month of pregnancy to the delivery process for at least 40 days and having direct involvement to the entire rituals. The urgency of this research was to give holistic perspective about psychological experiences of the Nuaulu women who underwent the exile so they would be able to undergo the rituals in good psychological conditions. The aims of this research were (1) to determine the influences of Psychological Well-Being and Meaning of Life toward the level of Religiosity viewed from Nuhune cultural ritual tradition, (2) to determine the difference of the influences of Psychological Well-Being and Meaning of Life toward the level of Religiosity of both primigravida and multigravida women. The hypothesis of this research was Psychological Well-Being and Meaning of Life as the predictor of the Religiosity level of primigravida and multigravida women.

\section{Material \& Methodology}

This research was done in Seram Island of Central Maluku regency. There were five villages which being chosen, they were Rohua, Bunara, Simalouw, Yalatan, and NuaNea. These villages were chosen since the villages were still continuously practicing the ritual of exile for women during $9^{\text {th }}$ month of pregnancy to the puerperium. Participants involved in this research were 150 adult women that divided into two categories; 75 of multigravida women and 75 of primigravida women. The samples were taken by proportional stratified random sampling, while the data collection was done by distributing questionnaire and having in-depth interview. Data analysis was done using multiple linear regressions. The scale of Psychological Well-Being was taken from Ryff[1], the scale of Meaning of Life was adapted 
from Steger, Frazier, Oishi \& Kaler [2], and the scale of Religiosity was taken from Glock and Stark[3].

\section{Results And Discussion \\ Results}

The result of the data analysis showed that Psychological Well-Being and Meaning of Life has simultaneously given significant influence the level of Religiosity of both primigravida and multigravida women.

Table 1

The Summary of Hypothesis Examination Result (Primigravida)

\begin{tabular}{l}
\hline \multicolumn{1}{c}{ Primigravida Women } \\
\hline \multicolumn{1}{c}{$\mathrm{R}=0,757$} \\
\hline $\mathrm{R}^{2}=0,572(57,2 \%)$ \\
\hline Effective Contribution \\
Psychological Well Being $=31,6 \%$ \\
Meaning of Life $=25,6 \%$ \\
\hline Dimension $P W B$ \\
Positive Relations with others $=19,3 \%$ \\
Autonomy $=18,6 \%$ \\
\hline Aspect of Meaning of Life \\
Willingness to a meaningful life $=29,1 \%$ \\
Meaning of Life = 14,3\%
\end{tabular}

The analysis result of table 1 showed that Psychological Well-Being contributed effectively toward the religiosity level of primigravida women for $31,6 \%$ most of which were influenced from positive relations dimension with others that contributed 19,3\%. Primigravida women could establish positive relations with others by being opened to their surroundings. Another dimension from Psychological Well-Being that effectively contributed toward the level of religiosity was the dimension of autonomy for $18,6 \%$. While the meaning of life of primigravida women contributed effectively for about $25,6 \%$ toward the religiosity level. However, the most influencing aspects to the willingness to construct a meaningful life contributed $29,1 \%$ while the aspect of meaning of life contributed $14,3 \%$. It means that primigravida women could see the aspect of achieving a meaningful life itself that contributed $14,3 \%$. Yet the $29,1 \%$ showed the values on how many people struggling from having willingness to achieve a meaningful life.

Table 2

The Summary of Hypothesis Examination Result (Multigravida)

\begin{tabular}{l}
\hline \multicolumn{1}{c}{ Multigravida Women } \\
\hline \multicolumn{1}{c}{$\mathrm{R}=0,773$} \\
\hline $\mathrm{R}^{2}=0,597(59,7 \%)$ \\
\hline Effective Contribution \\
PsychologicalWell Being $=12,7 \%$ \\
Meaning of Life $=47,0 \%$
\end{tabular}




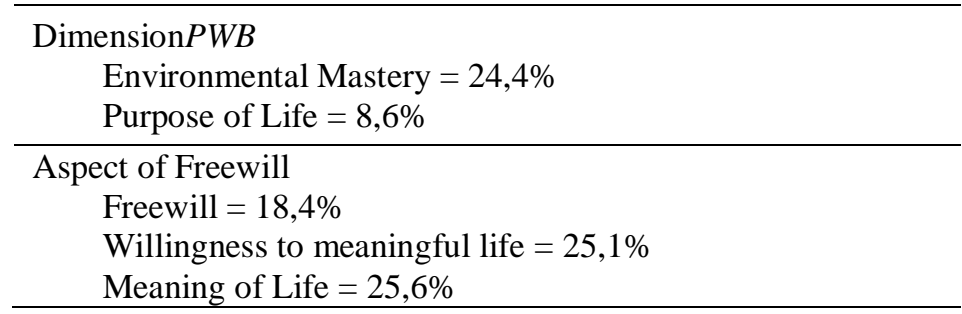

On table 2, the Psychological Well-Being of multigravida women contributed effectively for about $12,7 \%$ toward the religiosity level, and the Meaning of Life showed high contribution of $47 \%$ to the religiosity. It means that participation in the Meaning of Life itself was dominant in term of influence toward level of religiosity. Dimension that influenced Psychological Well Being most with $24,4 \%$ was Environmental Mastery and the purpose of life only take $8,6 \%$. While the willingness to construct a meaningful life as the most influencing variables toward religiosity which later was considered to be influenced by the Meaning of Life dimension for $25,6 \%$, the willingness to have a meaningful life contributed $25,1 \%$, and freewill contributed $18,4 \%$.

Table 3

\begin{tabular}{|c|c|c|}
\hline Zaccount & p-value & $\begin{array}{c}\text { Critical Value } \\
\text { Examination-Z }\end{array}$ \\
\hline$-3,30437$ & 0,00095 & 1,95996 \\
\hline
\end{tabular}

Table 3 showed that there was a significant difference between primigravida and multigravida with the value of examination point $\mathrm{Z}-3,30437$ and the significance level $0,00095(\mathrm{p}<0,05)$

\section{Discussion}

Psychological Well-Being has proven its contribution toward the Religiosity of primigravida women for $31,6 \%$. Positive relations with others seemed to be the most influencing dimension on Psychological Well-Being which contributed 19,3\%. Primigravida women tended to be able to establish positive connections with others and were opened to their surroundings. This is in line with what Ryff[1] mentioned previously saying that an individual who was on the high level of positive relations dimension with others was able to establish and maintain a warm and trustworthy relations with others. The individual would also have high level of sympathy toward others' affluence, and be able to give and establish a good relation to others. Women with high percentage on this dimension would open themselves, share love, and put trust with others. Sugianto[19] also supported that this positive attitude toward themselves was an important characteristic in the Psychological Well-Being. An optimal self-acceptance would show that the individual had the positive attitude toward herself and her surroundings, admitted and accepted many self-aspects including their strengths and weaknesses, and always felt positive toward her own life.

While in the other hand, the Autonomy dimension had the influence for about $18,6 \%$. It means that primigravida women tended to have a good confidence in facing their surroundings, including life-threatening dangers, and also being able to make decisions well over a problem. This could be seen from the determination of primigravida women when undergoing the exile that could possibly threaten their lives. Sugiyanto[20] firmly stated that 
an individual who had a high level of autonomy could be seen from their attitude in determining their own faith freely, enduring the social pressures, having a good selfexamination, and making decisions. To the Nuauluprimigravida women, they seemed to prioritize the positive relations with others than the autonomy. If Nuaulu women saw that there was a situation which was related to others and their own interests, then they would strengthen themselves to undergo whatever in their paths which were still based on the prevailing rules.

It was possible that Psychological Well-Being dimension which was able to make primigravida women adapt their environment and survive the life-threatening situations. Nuaulu women could feel peace in their lives because of having experienced good and bad occurrences during their lifetime.

The Meaning of Life to the primigravida women has contributed for about $25,6 \%$ toward the Religiosity. The women of primigravida saw the willingness to a meaningful life and the meaning of life itself as the focus when undergoing the exile ritual. The meaning of life as the will to achieve a meaningful life and also realization of a meaningful life could keep a Nuaulu woman strong to undergo her life. Nuaulu women who felt a prosperous peaceful life and were supported by the meaning of life showed the increase rate of Religiosity. According to Frank1[15], people who had the willingness to a meaningful life and realization to the high level of meaning of life tended to have the desire to motivate themselves when being suffered, especially when doing important activities which aimed to a precious meaningful life. If the meaning of life could satisfy the desire, then life would be meaningful and precious, so that it could be ensured that the level of Religiosity of Nuaulu women who lived under traditional rules increased.

Actually, primigravida women saw the traditional rituals as a practice which harmed their souls and lives although they would still obey and follow the traditions under their own anxieties. However, having the willingness to achieve the meaning of life and to have a meaningful life, they believed that this sacrifice had to be done in order to achieve their own salvation, and by believing in this principal, they could survive. Although the percentage of Religiosity was not as high as that of multigravida women, the primigravida women still saw the traditional practices as important things to do. The relation between the meaning of life and someone's age, and it was found in their research that the individuals with the range of age 25 years old and above tended to have higher scores of PIL (Purpose in Life) than the ones with the range of age between $13-24$ years old. Another research tried to integrate the meaning of life during the lifetime by doing analysis to every level of age development. It focused on the young adult (the final term of teenager) to the mid-adult aged, and the result showed that there was a significant difference between the two levels in achieving the meaning of life[2].

Meanwhile, the Psychological Well-Being of multigravida women contributed positively toward the Religiosity for $12,7 \%$. Psychological Well-Being received the most influencing dimensions which were Environmental Mastery for 24,4\% and the Purpose of Life for $8,6 \%$. Campton[21] said that individuals with good environmental mastery would be able to choose and change their surroundings to suit their needs. Multigravida women had high level of Psychological Well-Being, especially within the dimension of Environmental Mastery and Purpose of Life since they had undergone the exile quite often, and as a result, they could change their surroundings to be more comfortable and able to suit their needs. These abilities influenced their wants to have more children and undergo the rituals since they no longer felt fear. 
Ryff[1] said that individuals with good Psychological Well-Being would be able to choose and create an environment that suit their physical conditions needs. In other words, they would have the ability to adapt any occurrences beyond themselves. People with high level of environmental mastery were depicted by having abilities to manage their surroundings well, take opportunities within the environment, create a comfortable environment to themselves so that they could control their daily lives well. While people with high purposes in lives could have clear objectives and direction, and these people had a strong belief that they could achieve their life purposes by seeing that everything being undergone in their lives was meaningful[14].

The Meaning of Life had contributed positively toward Religiosity for $47,0 \%$ and it means that multigravida women saw the traditional rituals a meaningful circumstance and could help them be closer to God. This was ultimate point that they belief to achieve the real meaning of life and give them a brighter future. It could be seen from the three aspects of fulfilling the meaning of life and was considered important, and the three aspects were free will, willingness to have a meaningful life, and the meaning of life itself. Steger \& Frazier[2] also supported that the meaning of life could be seen as a connection between religiosity and psychological wellness, because one of the roles of a religion was giving guidance, and if people used the guidance, they would achieve their purposes in life[2]. This was also in line with Frankl[22] who said that they key to be a meaningful individual was by contributing ourselves and the environment in doing many things calmly based on inner consent and faith. Inner consent was able to transform an individual to become independent, unique, and meaningful. To multigravida women of Nuaulu, meaning of life enabled them to see themselves as meaningful and precious individuals in every unexpected situation in order to survive, so that they could continue their roles as good and wise Nuaulu women.

What was being undergone by primigravida women was in reverse from multigravida women. It happened because normally primigravida women underwent the ritual once and they were only below 25 years old. It influenced on how they see the ritual as a painful and hard practice to do, while multigravida women had undergone the ritual for more than twice, so they had the ability to construct meaning from undergoing the ritual and it happened as a result of realizing their own condition and by doing that they felt precious and proud of doing their daily activities. Grouden and Jose[23] found that women tended to have the ability to construct meaning of live better, because women were normally able to see and construct meanings behind of every pressure in life. This automatically made women to have more wide perspectives about life, and to think that whatever happened in their lives had to have precious meanings.

Besides, this research also found significant disparity of religiosity level between primigravida and multigravida women. Table 3 showed the significant difference by looking at the value of examination point $\mathrm{Z}$ being achieved was -3,30437 and the level of significance was $0,00095(\mathrm{p}<0,05)$. This means that there was a significant disparity of religiosity level between primigravida and multigravida seen from the category of pregnant women and undergoing the "Nuhune" exile. Range of age and more mature experiences were considered to contribute in the disparity level of multigravida women. Multigravida women believed that their previous experiences of giving birth and their faith were proven to prevent them from dangers. As a result, it would surely increase their religiosity level. Hathaway[24] also added that faith was similar to the activity of weaving. The more we weave the stronger and more beautiful it would become (weaving faith). Faith also influenced people on how to be strong when they have to undergo the weariness and supported them to decide their next paths. Thus, if women had undergone the exile for more than once, their faith would surely strong. 
Generally, both pirmigravida and multigravida women never left from any traditional practices within their own tribes because they knew that it was important not only for themselves but also for their family. Both women of primigravida and multigravida would surely never avoid the traditional practices within their tribes. According to Glock and Stark (in Reitsma[25]), religiosity focused on the concepts such as cognitive subjectivity, behavior dimensions, social, and culture where someone's level of religiosity could be seen from their attitude toward socio-cultural life that had shaped them to become an obedient person for their beliefs. Hence, the high level of religiosity owned by an individual would influence her daily attitude including the way they construct meaning toward the tradition of exile.

\section{Conclusion}

Referring to this research, it was known that simultaneously or partially Psychological Well-Being and Meaning of life had influenced the religiosity of both primigravida and multigravida Nuaulu women during the exile. Positive relations with others and autonomy were dimensions that also influenced the Psychological Well-Being. While in the other hand, free will, and the willingness to live meaningfully were dimensions that influenced the Meaning of Life. Besides, there were some significant disparities of religiosity level between multigravida and primigravida women.

This research also had benefit to increase the comprehension of the readers in the area of local wisdom-based psychology especially for the people of Maluku whom directly related to the ritual of Nuhune. This research could also be a reference for the Health Agency of Central Maluku to supervise some areas where some tribes like Nuaulu lives and practice the tradition of exile for women during pregnancy and puerperium. Furthermore, this research could also be a reference for women who were undergoing the ritual in order to adopt the concept of Psychological Well-Being and Meaning of Life during the time in exile.

The researcher suggested that the local government needed to improve the health quality of the local tribes such as Nuaulu, because economic and health facilities were limited which caused the children of Nuaulu did not care about their own health. The local government also needed to give information and comprehension about healthy traditional delivery process, and training to use sterilized equipment used by witch-doctors during the delivery process. This research was still limited since it was a quantitative research, and more information could be achieved better if examined using qualitative method.

\section{Acknowledgment}

This research is fully supported and financed by Hibah Penelitian Tim Pascasarjana by Kemenristek Dikti TA 2018

\section{References}

[1] D. C. Ryff, "Happiness is Everything, or is it? Exploration on the Meaning of Psychological Well-Being,” J. Personal. Soc. Psychol., 1989.

[2] m. K. M. Steger, p. Frazier, s. Oishi, "The Meaning in Life Questionnaire: Assessing the Presence of and Search for Meaning in Life," J. Couns. Psychol., vol. 53(1), pp. 80-93, 2006.

[3] R. S. C. Y. Glock, Religion and Society in Tension. San Francisco: Rand McNally, 1965.

[4] S. E. Sry, "Pengasingan Wanita Melahirkan Suku Nuaulu Di Dusun Rohua Kecamatan Amahai Kabupaten Maluku Tengah,” J. Ris. Kesehat., vol. 5 (1), pp. 14-20, 2016.

[5] N. Johan, Perempuan Nuaulu Tradisionalisme dan Kultur Patriarki. Jakarta: Yayasan 
Pustaka Obor Indonesia, 2012.

[6] U. R. Wati, Pengembangan Civic Culture Melalui Pendidikan Formal dan Budaya Lokal Masyarakat Suku Nuaulu. Bandung: Universitas Pendidikan Indonesia, 2015.

[7] G. B. P. E. Flouri, S. Ioakeimidi, E. Midouhas, "Maternal Psychological Distress and Child Decision-making,” J. Affect. Disord., vol. 218, pp. 35-40, 2017.

[8] M. V. K. Noonan, R. Burns, "Family Income, Maternal Psychological Distress and Child Socio-emotional behaviour: Longitudinal findings," UK Millenn. Cohort Study, vol. 4, pp. 280-290, 2018.

[9] E. Andriana, Melahirkan Tanpa Rasa Sakit dengan Metode Relaksasi Hypno Birthing. Jakarta: PT Bhuana Ilmu Populer, 2011.

[10] B. R. Y. Aprilia, Gentle Birth: Melahirkan Nyaman Tanpa Rasa Sakit. Jakarta: PT Gramedia Widiasarana Indonesia, 2011.

[11] Y. Astria, "Hubungan Karakteristik Ibu Hamil Trimester III dengan Kecemasan dalam Menghadapi Persalinan di Poliklinik Kebidanan dan Kandungan RSUP Fatmawati," Universitas Islam Negeri Jakarta, 2009.

[12] Indrawati, "Faktor-Faktor yang Mempengaruhi Tingkat Kecemasan pada Ibu Primigravida dalam Menghadapi Persalinan,” J. Keperawatan, vol. 11, No. 1, 2010.

[13] T. E. B. Novitasari Trias, "Developmental and Clinical Psychology: Keefektivan Konseling Kelompok Pra-Persalinan Untuk Menurunkan Tingkat Kecemasan Primigravida Menghadapi Persalinan," J. Psikol. Fak. Ilmu Pendidik. Univ. Negeri Semarang, 2013.

[14] M. S. U. Sukma Adi Galuh Amawidyati, "No TitleaReligiusitas dan Psychological Well Being Pada Korban Gempa,” J. Psikol., vol. 34, pp. 164-176, 2007.

[15] V. E. Frankl, The Rediscovery of the Human: Basic Texts of Viktor E. Frankl. Bern: Hans Huber, 2005.

[16] V. E. Frankl, The Will to Meaning, Foundations dan Aplications of Logotherapy. New York: Meridian, 1988.

[17] S. A. A. A. Azam, F. Qiang, M.I. Abdulah, "Impact of 5-d of Religiosity on Diffusion Rate of Innovation," J. Bus. Soc. Sci., vol. 2 (17), pp. 177-185, 2012.

[18] L. Yoselita, Jurnal Ritual Sebagai Daya Tarik Ekowisata Di Desa Nua Nea Kabupaten Maluku Tengah. Ambon: Universitas Pattimura, 2015.

[19] I. R. Sugianto, "Status Lajang dan Psychological Well-Being pada Pria dan Wanita," J. Phronesis, 2000.

[20] Sugiyanto, Model-model Pembelajaran Inovatif. Surakarta: UNS Press, 2009.

[21] W. C. Campton, An Introduction to Positive Psychology. New York: Thomson Wadsworth, 2005.

[22] V. E. Frankl, Man Searching for Meaning: Mencari Makna Hidup. Bandung: Nuansa, 2004.

[23] P. E. J. M.E. Grouden, "How do Sources of Meaning in Life Vary According to Demographic Factors?," NZ. J. Psychol., vol. 43 (3), pp. 29-38, 2014.

[24] P. C. Hathaway, Weaving Faith And Experience: A Woman's Perspective. Franciscan Media, 2010.

[25] P. S. J. Reitsma, "Dimensions of individual religiosity and charity: Cross national effect differencesin European countries?," Rev. Relig. Res., vol. 47 (4), pp. 347-362, 2006. 